\title{
Pengaruh Beamwidth, Gain dan Pola Radiasi terhadap Performansi Antena Penerima
}

\author{
Andi Sri Irtawaty, S.T., M.Eng. ${ }^{1}$, Maria Ulfah, S.T., M.T. ${ }^{2}$, Hadiyanto, S.T.,M.Eng ${ }^{3}$ \\ ${ }^{1,2,3}$ Politeknik Negeri Balikpapan , Jalan Soekarno Hatta Km 8, Balikpapan
}

Email : andi.sri@poltekba.ac.id

\begin{abstract}
In this research, measurements of beamwidth, gain and radiation pattern to determine the performance of the receiving antenna. There are 4 types of receiving antennas to be tested using 3 parameters of measurement (beamwidth, gain and radiation pattern), they are dipole antenna, monopole antenna, circular loop antenna and yagi antenna [6]. In the performance testing of the four receiving antennas, the yagi antenna is used as a transmitting antenna.The process of measuring the parameters of antenna yagi as transmitter antenna and dipole antenna, monopole antenna, circular loop antenna and yagi antenna as the receiving antenna is done by an antenna trainer with supporting software. Data retrieval is done in 2 conditions namely Line Of Sight (LOSS) and using obstacle (NO-LOSS). The distance between the transmitting antenna and the receiving antenna is 1.5 meters, 2 meters, 2.5 meters, 3 meters and 5 meters. The slope position of the antenna is also a determining factor in the measurement process. There are 3 categories namely, horizontal (antenna sender) and horizontal (antenna receiver), vertical (antenna sender) and vertical (antenna receiver) and combination of horizontal (antenna sender) and vertical (antenna receiver). The measuring distance between the transmitting antenna and the receiving antenna tested is 1.5 meters, 2 meters, 2.5 meters, 3 meters and 5 meters. The results of antenna quality testing show that among the four types of antenna (dipole, monopole, circular loop and yagi), it is proven that the yagi antenna has a very perfect test accuracy level of $100 \%$. The yagi antenna is proven to have the best performance as a receiving antenna compared to the dipole antenna , monopole antenna and circular loop antenna for more coverage.
\end{abstract}

Keywords: beamwidth, gain, radiation pattern.

\begin{abstract}
Abstrak
Pada penelitian ini akan dilakukan pengukuran beamwidth, gain dan pola radiasi untuk mengetahui performansi antenna penerima. Ada 4 jenis antenna penerima yang akan diuji dengan menggunakan 3 parameter ukur (beamwidth, gain dan pola radiasi), yaitu antenna dipole, antenna monopole, antenna circular loop dan antenna yagi. [6 ] Dalam pengujian performansi keempat antenna penerima tersebut, digunakan antenna yagi sebagai antenna pemancar.Proses pengukuran parameter-parameter antenna yagi sebagai antenna pemancar dan antenna dipole, antenna monopole, antenna circular loop dan antenna yagi sebagai antenna penerima dilakukan dengan sebuah alat/ trainer antenna yang dilengkapi software pendukung. Pengambilan data dilakukan pada 2 kondisi yaitu secara Line Of Sight (LOSS) dan menggunakan obstacle (NO-LOSS). Jarak antara antenna pemancar dan antenna penerima yaitu 1.5 meter, 2 meter, 2.5 meter, 3 meter dan 5 meter. Posisi kemiringan antenna juga menjadi faktor penentu dalam proses pengukuran. Ada 3 kategori yaitu, horisontal (antenna pengirim) dan horisontal (antenna penerima), vertical (antenna pengirim) dan vertical (antenna penerima) serta kombinasi horizontal (antenna pengirim) dan vertical (antenna penerima). Jarak ukur antara antenna pemancar dan antenna penerima yang diujikan adalah 1.5 meter, 2 meter, 2.5 meter, 3 meter dan 5 meter. Hasil pengujian kualitas antenna menunjukkan bahwa diantara 4 jenis antenna (dipole, monopole, circular loop dan yagi), terbukti bahwa antenna yagi memiliki tingkat akurasi pengujian yang sangat sempurna sebesar $100 \%$.. Antena yagi terbukti memiliki performansi yang terbaik sebagai antenna penerima dibandingkan antenna dipole, antenna monopole dan antenna circular loop untuk jangkauan coverage yang lebih jauh.
\end{abstract}

Kata kunci: beamwidth, gain, pola radiasi

\section{PENDAHULUAN Latar Belakang}

Antena (antenna atau areal) adalah perangkat yang berfungsi untuk memindahkan energi gelombang elektromagnetik dari media kabel ke udara atau sebaliknya dari udara ke media kabel. Karena merupakan perangkat perantara antara media kabel dan udara, maka antena harus mempunyai sifat yang sesuai (match) dengan media kabel pencatunya. Prinsip ini telah diterangkan dalam saluran transmisi. [1] Untuk mengetahui kualitas suatu antena, beberapa parameter ukur harus diujikan [2] [3] [9] [10] yaitu;

- gain,

- pola radiasi,

- lebar band (bandwidth),

- besar sudut berkas pancaran 
gelombang (beamwidth),

- impedansi input yang dimiliki,

- directivitas.

Berdasarkan fungsinya antenna

dibedakan dalam 2 macam yaitu : antenna pemancar dan antena penerima. Sifat antena ada dua yaitu omnidirectional dan directional. [5]

Dalam sejarah komunikasi, perkembangan teknik informasi tanpa menggunakan kabel ditetapkan dengan nama "Antena". Antena berasal dari bahasa latin "Antena" yang berarti "tiang kapal layar". Dalam pengertian sederhana kata latin ini berarti juga "penyentuh atau peraba" sehingga kalau dihubungkan dengan teknik komunikasi berarti bahwa antena mempunyai tugas menyelusuri jejak gelombang elektromagnetik, hal ini jika antena berfungsi sebagai penerima. Sedangkan jika sebagai pemancar maka tugas antena tersebut adalah menghasilkan sinyal gelombang elektromagnetik. [10]. Sinyal gelombang radiasi elektromagnetik yang berasal dari antena terdiri dari dua komponen yaitu medan listrik dan medan magnetik. Antena pemancar dibagi menjadi dua klasifikasi dasar yaitu: Antena Hertz (half-wave) dan Antena Marconi (quarterwave).[7]

Adapun symbol antenna disajikan pada gambar 1 dibawah ini:

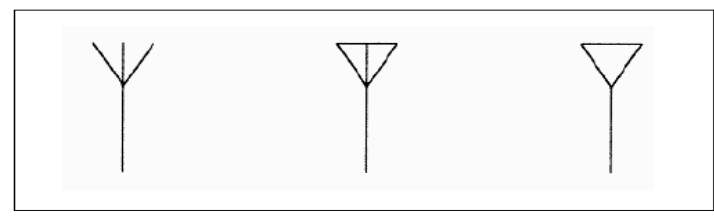

Gambar 1. Simbol antena

Sumber : [1]

Sifat antena ada dua yaitu omnidirectional dan directional. Antena directional,yaitu antena yang mempunyai pola pemancaran sinyal dengan satu arah tertentu. Antena ini idealnya digunakan sebagai penghubung antar gedung atau untuk daerah (konfigurasi Point to Point) yang mempunyai konfigurasi cakupan area yang kecil seperti pada lorong-lorong yang panjang. [8]. Antena jenis directional merupakan jenis antena dengan narrow beamwidth, yaitu punya sudut pemancaran yang kecil dengan daya lebih terarah, jaraknya jauh dan tidak bisa menjangkau area yang luas, antena directional mengirim dan menerima sinyal radio hanya pada satu arah, umumnya pada fokus yang sangat sempit, dan biasanya digunakan untuk koneksi point to point, atau multiple point, contoh antena directional seperti antena grid, dish "parabolic", yagi, dan antena sectoral. Yang termasuk antenna directional adalah antena model yagi seperti kebanyakan yang dipakai sebagai antena penerima siaran TV. Antenna yagi, dengan logperiodik antena, dan sudut reflektor, yang sering digabungkan dan dijual sebagai hunian komersial antena TV [5]. Antenna Omnidirectional dapat memancarkan gelombang ke segala arah. Salah satu antenna jenis omnidirectional adalah antenna monopole. Pola radiasinya adalah ke segala arah. [4] . Semua antena secara umum baik bentuk dan ukurannya mempunyai empat karakteristik dasar yaitu directivity, gain, polarization dan beamwidth. [7].

Selain pola radiasi, parameter penting yang akan diujikan dalam penelitian ini adalah beamwidth dan gain antenna. Beamwidth adalah besarnya sudut berkas pancaran gelombang frekuensi radio utama (main lobe) yang dihitung pada titik $3 \mathrm{~dB}$ menurun dari puncak lobe utama. [5] . Gain antenna adalah karakter antenna yang terkait dengan kemampuan antenna mengarahkan radiasi sinyalnya, atau penerimaan sinyal dari arah tertentu. Satuannya adalah $\mathrm{dB}$, dBm atau dBi. [6].

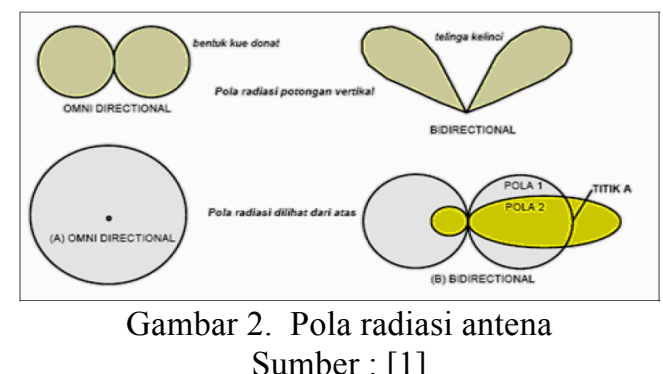

\section{Rumusan Masalah}

Pada penelitian ini, akan dilakukan pengujian performansi empat jenis antena penerima yaitu antenna dipole, antenna monoipole, antenna circular dipole dan antenna yagi, secara bergantian. Parameter uji yang digunakan ada 3, yaitu beamwidth, gain dan pola radiasi. Pengujian ini dilakukan dengan beberapa kondisi, yaitu :

1. Kondisi Line of Sight (LOSS) dan kondisi dengan menggunakan obstacle (NO-LOSS).

2. Posisi kemiringan antenna yaitu E-plane, H-plane dan kombinasi E-plane dan $H$-plane.

3. Jarak pengujian antenna pemancar dan antenna penerima adalah 1,5 meter, 2 meter, 2.5 meter, 3 meter dan 5 meter untuk frekuensi $500 \mathrm{MHz}$. 


\section{Tujuan Penelitian} berikut:

Tujuan khusus penelitian ini sebagai

1. Mengukur dan menganalisa beamwidth, gain dan pola radiasi antenna dipole sebagai antenna penerima.

2. Mengukur dan menganalisa beamwidth, gain dan pola radiasi antenna monopole sebagai antenna penerima.

3. Mengukur dan menganalisa beamwidth, gain dan pola radiasi antenna circular loop sebagai antenna penerima.

4. Mengukur dan menganalisa beamwidth, gain dan pola radiasi antenna yagi sebagai antenna penerima.

5. Membandingkan hasil analisa dari poin 1 sampai poin 4 untuk menentukan performansi antenna penerima yang terbaik.

\section{METODOLOGI}

\section{Bahan Dan Peralatan Utama}

Bahan dan peralatan utama dalam penelitian ini meliputi trainer antenna, laptop, antena dipole, antena monopole, antena circular loop, antena yagi, kabel koaksial, dan triplek sebagai penghalang.

\section{Metode Penelitian}

Tahapan-tahapan dalam metode peneltian ini meliputi:

1. Tahap I (Persiapan)

Tahap ini meliputi tahap persiapan studi literatur dari permasalahan yang dikemukakan.

2. Tahap II (Penelitian)

Dalam tahap penelitian dilakukan proses perancangan flowchart, yang akan mendeskripsikan langkah-,langkah dalam pengambilan data uji.

3. Tahap III (Analisis Data)

Pada tahap ini, semua data yang diperoleh, akan dianalisa dengan membandingkan hasil pengukuran karakteristik dengan nilai idealnya secara teoritis.

4. Tahap IV (Kesimpulan)

Tahap terakhir adalah kesimpulan. Kesimpulan diambil berdasarkan hasil analisa yang diperoleh.

\section{Flowchart}

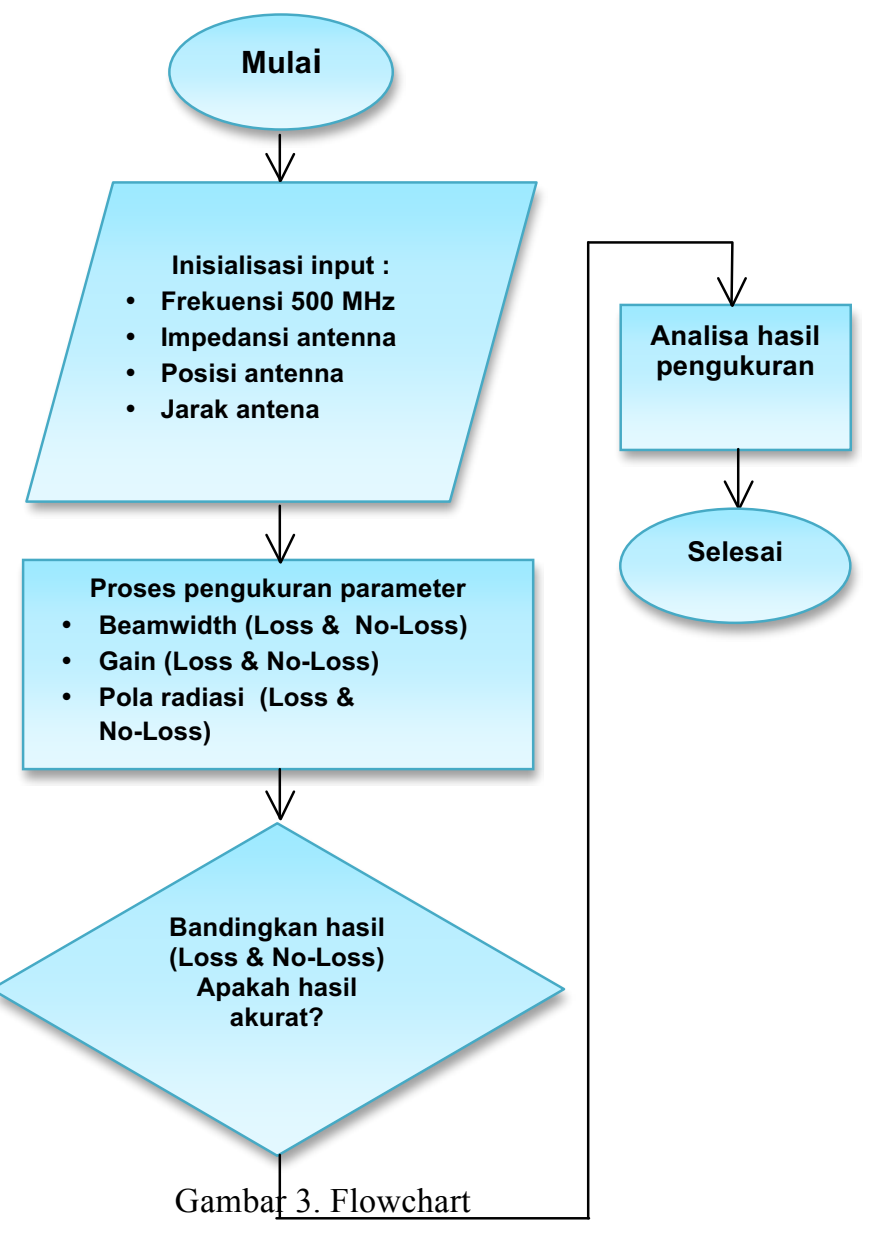

Teknik Pengumpulan data dilakukan secara observasi yaitu dengan melakukan pencatatan data terhadap 3 parameter ukur yang diuji untuk masing-masing antenna penerima. Hasilnya akan dibandingkan untuk mengetahui performansi antenna penerima yang terbaik untuk cakupan coverage yang jauh.

\section{HASIL DAN PEMBAHASAN}

Dalam menganalisa hasil pengukuran gain dan pola radiasi dalam penelitian ini dilakukan dengan beberapa kondisi:

1. Kondisi antenna pemancar dan antenna penerima bersifat LOSS dan NO-LOSS.

2. Posisi kemiringan antenna pemancar dan antenna penerima yaitu kombinasi E-plane (horizontal) dan H-plane (vertical).

3. Jarak antara antena pemancar dan antena penerima ada 5 variasi, yaitu 1.5 meter, 2 meter, 2.5 meter, 3 meter 5 meter.

Pengukuran beamwidth, gain dan pola radiasi antenna dilakukan mulai dari azimuth $0^{0}$ sampai $330^{\circ}$. Hasil pengukuran selengkapnya akan disajikan secara step by step terhadap keempat antenna penerima (antenna dipole, antenna 
monopole, antenna circular loop dan antenna yagi).

\section{Pengukuran Beamwidth, Gain dan Pola radiasi Antenna Dipole pada kondisi Loss}

Nilai gain minimum pada jarak 1.5 meter, sebesar -20 dB (E-plane) dan -14 dB (H-plane) pada sudut $210^{\circ}$. Pada jarak 2 meter, nilai gain minimum antenna dipole juga sebesar $-20 \mathrm{~dB}$ (E-plane) dan -20 dB (H-plane) pada sudut $60^{\circ}$, $90^{\circ}, 270^{\circ}$ dan $300^{\circ}$. Demikian pula pada jarak 2.5 meter, 3 meter dan 5 meter, terlihat nilai gain minimum antenna dipole sebesar $-20 \mathrm{~dB}$. Ini berarti bahwa beamwidth antenna dipole sebesar -20 dB dikurangi setengah daya $3 \mathrm{~dB}$, maka diperoleh $-23 \mathrm{~dB}$, sehingga half power beamwidth vertical (untuk jarak 1.5 meter) sebesar $70^{\circ}+45^{\circ}=115^{\circ}$, seperti yang terlihat pada gambar 4 berikut :

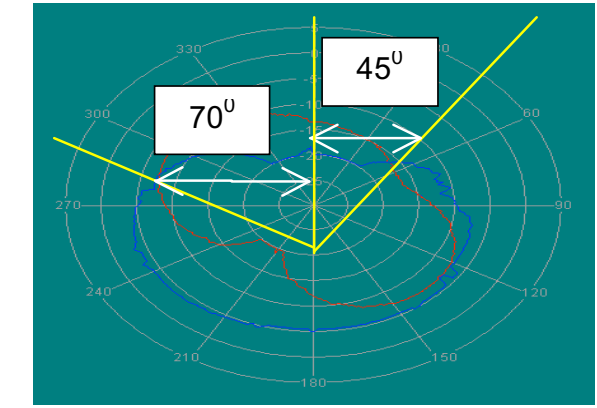

Gambar 4. Perhitungan lebar sudut beamwidth

Hasil pengukuran gain rata-rata antenna dipole pada kondisi LOSS selengkapnya disajikan pada tabel 1 .

Tabel 1 Nilai gain rata-rata antenna dipole kondisi Loss

\begin{tabular}{ccccc}
\hline \multirow{2}{*}{$\begin{array}{c}\text { Jarak } \\
\text { antenna } \\
\text { (meter) }\end{array}$} & $\begin{array}{c}\text { E-Plane } \\
\text { (horizontal- } \\
\text { horisontal) }\end{array}$ & $\begin{array}{c}\text { H-Plane } \\
\text { (vertical- } \\
\text { vertikal) }\end{array}$ & $\begin{array}{c}\text { Kombinasi E-Plane } \\
\text { dan H-Plane } \\
\text { (horizontal }- \\
\text { vertical) }\end{array}$ \\
\cline { 4 - 6 } $\mathbf{1 . 5}$ & $-11.8 \mathrm{~dB}$ & $-9.4 \mathrm{~dB}$ & $-13.3 \mathrm{~dB}$ & $-13.2 \mathrm{~dB}$ \\
\hline $\mathbf{2}$ & $-18.6 \mathrm{~dB}$ & $-14.7 \mathrm{~dB}$ & $-18.6 \mathrm{~dB}$ & $-19 \mathrm{~dB}$ \\
\hline $\mathbf{2 . 5}$ & $-20 \mathrm{~dB}$ & $-18 \mathrm{~dB}$ & $-19.9 \mathrm{~dB}$ & $-19.7 \mathrm{~dB}$ \\
\hline $\mathbf{3}$ & $-20 \mathrm{~dB}$ & $-20 \mathrm{~dB}$ & $-20 \mathrm{~dB}$ & $-20 \mathrm{~dB}$ \\
\hline $\mathbf{5}$ & $-20 \mathrm{~dB}$ & $-20 \mathrm{~dB}$ & $-20 \mathrm{~dB}$ & $-20 \mathrm{~dB}$ \\
\hline $\begin{array}{c}\text { Gain } \\
\text { rata-rata }\end{array}$ & $\mathbf{- 1 8 . 1 ~ d B}$ & $\mathbf{- 1 6 . 4 ~ d B}$ & $\mathbf{- 1 8 . 4 ~ d B}$ & $\mathbf{- 1 8 . 4 ~ d B}$ \\
\hline
\end{tabular}

Secara teoritis, semakin bertambah jarak antenna, maka nilai gain antenna akan semakin berkurang. Ada 20 nilai gain rata-rata antenna dipole yang terukur dan disajikan pada tabel 1 .

Hasilnya menunjukkan bahwa nilai gain yang terukur selaras dengan pernyataan teoritisnya. Berarti prosentase keakuratan hasil pengukuran gain dapat diperoleh dengan rumus berikut :

$$
\begin{aligned}
& \% \text { keakuratan }=\frac{\mathrm{N} \text { data terukur- } \mathrm{N} \text { data error }}{\mathrm{N} \text { data terukut }} \times 100 \% \\
& \% \text { keakuratan }=\frac{(20-0)}{20} \times 100 \%=100 \%
\end{aligned}
$$

\section{Pengukuran Beamwidth, Gain dan Pola radiasi Antenna Dipole pada kondisi No- Loss}

Nilai gain minimum pada jarak 1.5 meter, sebesar -20 dB (E-plane) dan -12 dB (H-plane) pada sudut $30^{\circ}$. Nilai gain minimum antenna dipole pada jarak 2 meter, 2.5 meter, 3 meter dan 5 meter sebesar -20 dB (E-plane) dan $-20 \mathrm{~dB}$ (H-plane) seperti yang disajikan pada tabel 2. Ini berarti bahwa beamwidth antenna dipole pada kondisi No-Loss sebesar -20 dB dikurangi setengah daya $3 \mathrm{~dB}$, maka diperoleh $23 \mathrm{~dB}$, sehingga half power beamwidth vertical (untuk jarak 1.5 meter) sebesar $10^{\circ}+80^{\circ}=90^{\circ}$, seperti yang terlihat pada gambar 5 berikut :

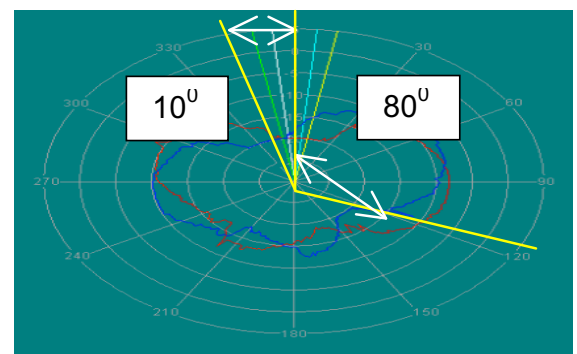

Gambar 5. Perhitungan lebar sudut beamwidth

Hasil pengukuran gain rata-rata antenna dipole pada kondisi NO-LOSS dan 3 variasi posisi antenna dipole yaitu E-plane, H-plane dan kombinasi (E-plane dan H-plane) akan disajikan pada tabel 2 .

Tabel 2 Nilai gain rata-rata antenna dipole kondisi No-Loss

\begin{tabular}{ccccc}
\hline \multirow{2}{*}{$\begin{array}{c}\text { Jarak } \\
\text { antenna } \\
\text { (meter) }\end{array}$} & $\begin{array}{c}\text { E-Plane } \\
\text { (horizontal- } \\
\text { horisontal) }\end{array}$ & $\begin{array}{c}\text { H-Plane } \\
\text { (vertical } \\
\text { vertikal) }\end{array}$ & $\begin{array}{c}\text { Kombinasi E-Plane dan } \\
\text { H-Plane }\end{array}$ \\
\cline { 4 - 6 } & & \multicolumn{2}{c}{$\begin{array}{c}\text { E-Plane } \\
\text { (horizontal - vertical) }\end{array}$} & H-Plane \\
\hline $\mathbf{1 . 5}$ & $-12.21 \mathrm{~dB}$ & $-13.4 \mathrm{~dB}$ & $-13.84 \mathrm{~dB}$ & $-14.42 \mathrm{~dB}$ \\
$\mathbf{2}$ & $-19.01 \mathrm{~dB}$ & $-15.43 \mathrm{~dB}$ & $-18.72 \mathrm{~dB}$ & $-18.99 \mathrm{~dB}$ \\
$\mathbf{2 . 5}$ & $-19.06 \mathrm{~dB}$ & $-14.19 \mathrm{~dB}$ & $-19.22 \mathrm{~dB}$ & $-19.24 \mathrm{~dB}$ \\
$\mathbf{3}$ & $-20.0 \mathrm{~dB}$ & $-20.0 \mathrm{~dB}$ & $-20.0 \mathrm{~dB}$ & $-20.0 \mathrm{~dB}$ \\
$\mathbf{5}$ & $-20.0 \mathrm{~dB}$ & $-20.0 \mathrm{~dB}$ & $-20.0 \mathrm{~dB}$ & $-20.0 \mathrm{~dB}$ \\
\hline $\begin{array}{c}\text { Gain } \\
\text { rata-rata }\end{array}$ & $\mathbf{- 1 8 . 1} \mathbf{d B}$ & $\mathbf{- 1 6 . 4 ~ d B}$ & $\mathbf{- 1 8 . 4} \mathbf{d B}$ & $\mathbf{- 1 8 . 5 ~ d B}$ \\
\hline
\end{tabular}


Berdasarkan tabel 2 terlihat ada 2 data yang error, yaitu pada kondisi H-plane, yaitu pada jarak 2 meter, nilai gain rata-rata antenna dipole -15.43 dB sedangkan pada jarak 2.5 meter, nilai gain rata-rata antenna dipole $-14.19 \mathrm{~dB}$. Berarti prosentase keakuratan hasil pengukuran gain adalah sebagai berikut :

$$
\% \text { keakuratan }=\frac{(20-2)}{20} \times 100 \%=90 \%
$$

\section{Pengukuran Beamwidth, Gain dan Pola} radiasi Antenna Monopole pada kondisi Loss Nilai gain minimum pada jarak 1.5 meter, sebesar -20 dB (E-plane) dan -14 dB (H-plane) pada sudut $30^{\circ}$. Nilai gain minimum antenna monopole pada jarak 2 meter, 2.5 meter, 3 meter dan 5 meter sebesar $-20 \mathrm{~dB}$ (E-plane) dan -20 dB (H-plane) seperti yang disajikan pada tabel 4. Ini berarti bahwa beamwidth antenna monopole pada kondisi No-Loss sebesar -20 $\mathrm{dB}$ dikurangi setengah daya $3 \mathrm{~dB}$, maka diperoleh $-23 \mathrm{~dB}$, sehingga half power beamwidth vertical (untuk jarak 1.5 meter) sebesar $45^{\circ}+85^{\circ}=130^{\circ}$, seperti yang terlihat pada gambar 6 berikut :

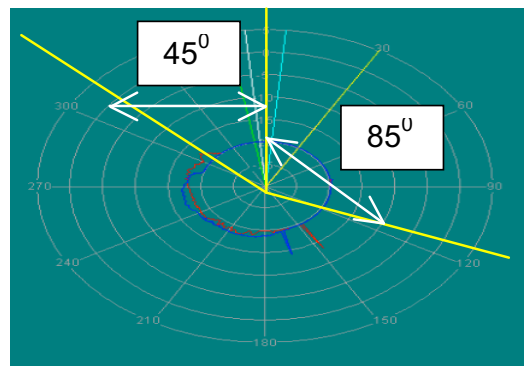

Gambar 6. Perhitungan Lebar Sudut Beamwidth

Hasil pengukuran gain rata-rata antenna monopole pada kondisi LOSS dan 3 variasi posisi antenna monopole yaitu E-plane, H-plane dan kombinasi (E-plane dan H-plane) akan disajikan pada tabel 3 .

Tabel 3. Nilai gain rata-rata antenna monopole kondisi LOSS

\begin{tabular}{ccccc}
\hline \multirow{2}{*}{$\begin{array}{c}\text { Jarak } \\
\text { antenna } \\
\text { (meter) }\end{array}$} & $\begin{array}{c}\text { E-Plane } \\
\text { (horizontal- } \\
\text { horisontal) }\end{array}$ & $\begin{array}{c}\text { H-Plane } \\
\text { (vertical- } \\
\text { vertikal) }\end{array}$ & $\begin{array}{c}\text { Kombinasi E-Plane } \\
\text { dan H-Plane } \\
\text { (horizontal - vertical) }\end{array}$ \\
\cline { 4 - 6 } $\mathbf{1 . 5}$ & $-12.4 \mathrm{~dB}$ & $-16.1 \mathrm{~dB}$ & $-14.2 \mathrm{~dB}$ & $-14.6 \mathrm{~dB}$ \\
$\mathbf{2}$ & $-19.9 \mathrm{~dB}$ & $-17.3 \mathrm{~dB}$ & $-15.8 \mathrm{~dB}$ & $-15.5 \mathrm{~dB}$ \\
$\mathbf{2 . 5}$ & $-19.5 \mathrm{~dB}$ & $-19.5 \mathrm{~dB}$ & $-19.2 \mathrm{~dB}$ & $-18.5 \mathrm{~dB}$ \\
$\mathbf{3}$ & $-20.0 \mathrm{~dB}$ & $-20.0 \mathrm{~dB}$ & $-20.0 \mathrm{~dB}$ & $-20.0 \mathrm{~dB}$ \\
$\mathbf{5}$ & $-20.0 \mathrm{~dB}$ & $-20.0 \mathrm{~dB}$ & $-20.0 \mathrm{~dB}$ & $-20.0 \mathrm{~dB}$ \\
\hline
\end{tabular}

$\begin{gathered}\text { Gain } \\ \text { rata-rata }\end{gathered} \quad-\mathbf{1 8 . 3 6 \mathrm { dB }} \quad-\mathbf{1 8 . 5 8 \mathrm { dB }} \quad-\mathbf{1 7 . 8 4 \mathrm { dB }} \quad \mathbf{- 1 7 . 7 2 \mathrm { dB }}$

Nilai gain antenna monopole yang disajikan pada tabel 3 memperlihatkan pada kondisi pengukuran gain E-plane, terjadi penyimpangan teori yaitu pada jarak 2 meter, nilai gain rata-rata -19.9 dB dan pada jarak 2.5 meter, nilai gain rata-rata $-19.5 \mathrm{~dB}$. Berarti prosentase keakuratan hasil pengukuran gain rata-rata antenna monopole kondisi LOSS adalah sebagai berikut berikut :

$$
\% \text { keakuratan }=\frac{(20-2)}{20} \times 100 \%=90 \%
$$

\section{Pengukuran Beamwidth, Gain dan Pola radiasi Antenna Monopole pada kondisi No- Loss}

Nilai gain minimum pada jarak 1.5 meter, sebesar -20 dB (E-plane) dan -20 dB (H-plane) pada sudut $0^{0}$. Nilai gain minimum antenna monopole pada jarak 2 meter, 2.5 meter, 3 meter dan 5 meter sebesar $-20 \mathrm{~dB}$ (E-plane) dan $-20 \mathrm{~dB}$ (H-plane) seperti yang disajikan pada tabel 4. Ini berarti bahwa beamwidth antenna monopole pada kondisi No-Loss sebesar $-20 \mathrm{~dB}$ dikurangi setengah daya $3 \mathrm{~dB}$, maka diperoleh $23 \mathrm{~dB}$, sehingga half power beamwidth vertical (untuk jarak 1.5 meter) sebesar $52^{\circ}$, seperti yang terlihat pada gambar 7 berikut :

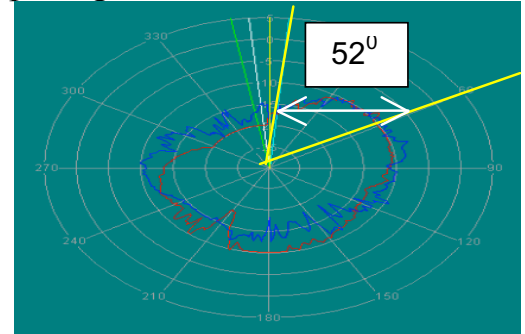

Gambar 7. Perhitungan Lebar Sudut Beamwidth

Hasil pengukuran gain rata-rata antenna monopole pada kondisi NO-LOSS dan 3 variasi posisi antenna monopole yaitu E-plane, H-plane dan kombinasi (E-plane dan H-plane) akan

\begin{tabular}{|c|c|c|c|c|}
\hline \multirow[t]{2}{*}{$\begin{array}{c}\text { Jarak } \\
\text { antenna } \\
\text { (meter) }\end{array}$} & \multirow[t]{2}{*}{$\begin{array}{c}\text { E-Plane } \\
\text { (horizontal } \\
- \\
\text { horisontal) }\end{array}$} & \multirow[t]{2}{*}{$\begin{array}{l}\text { H-Plane } \\
\text { (vertical- } \\
\text { vertikal) }\end{array}$} & \multicolumn{2}{|c|}{$\begin{array}{l}\text { Kombinasi E- } \\
\text { Plane dan H-Plane } \\
\text { (horizontal - } \\
\text { vertical) }\end{array}$} \\
\hline & & & E-Plane & H-Plane \\
\hline 1.5 & $-12.4 \mathrm{~dB}$ & $-16.1 \mathrm{~dB}$ & $-14.2 \mathrm{~dB}$ & $-14.6 \mathrm{~dB}$ \\
\hline 2 & $-19.9 \mathrm{~dB}$ & $-17.3 \mathrm{~dB}$ & $-15.8 \mathrm{~dB}$ & $-15.5 \mathrm{~dB}$ \\
\hline 2.5 & $-19.5 \mathrm{~dB}$ & $-19.5 \mathrm{~dB}$ & $-19.2 \mathrm{~dB}$ & $-18.5 \mathrm{~dB}$ \\
\hline 3 & $-20.0 \mathrm{~dB}$ & $-20.0 \mathrm{~dB}$ & $-20.0 \mathrm{~dB}$ & $-20.0 \mathrm{~dB}$ \\
\hline
\end{tabular}
disajikan pada tabel 4 .

Tabel 4. Nilai gain rata-rata antenna monopole pada kondisi NoLoss 


\begin{tabular}{|ccccc}
\multicolumn{5}{l}{ JURNAL TEKNOLOGI TERPADU Vol. 6 No. 1 April 2018} \\
\hline $\mathbf{5}$ & $-20.0 \mathrm{~dB}$ & $-20.0 \mathrm{~dB}$ & $-20.0 \mathrm{~dB}$ & $-20.0 \mathrm{~dB}$ \\
\hline $\begin{array}{c}\text { Gain } \\
\text { rata-rata }\end{array}$ & $\mathbf{- 1 8 . 3 6} \mathbf{d B}$ & $\mathbf{- 1 8 . 5 8} \mathbf{d B}$ & $\mathbf{- 1 7 . 8 4} \mathbf{~ d B}$ & $\mathbf{- 1 7 . 7 2} \mathbf{~ d B}$ \\
\hline
\end{tabular}

Nilai gain antenna monopole yang disajikan pada tabel 4 memperlihatkan hasil pengukuran gain rata-rata pada kondisi kombinasi E-plane $H$-plane, terjadi penyimpangan teori yaitu pada jarak 2 meter, nilai gain rata-rata pada E-plane $-19.5 \mathrm{~dB}$ dan pada jarak 2.5 meter, nilai gain ratarata E-plane $-19.2 \mathrm{~dB}$. Demikian pula untuk H-plane kombinasi, pada jarak 2 meter, nilai gain rata-rata $-19.4 \mathrm{~dB}$ dan pada jarak 2.5 meter, nilai gain rata-rata $-18.5 \mathrm{~dB}$. Berarti prosentase keakuratan hasil pengukuran gain rata-rata antenna monopole kondisi NO-LOSS dapat diperoleh dengan rumus berikut :

$$
\% \text { keakuratan }=\frac{(20-4)}{20} \times 100 \%=80 \%
$$

\section{Pengukuran Beamwidth, Gain dan Pola radiasi Antenna Circular Loop pada kondisi Loss}

Nilai gain minimum pada jarak 1.5 meter, sebesar -20 dB (E-plane) dan -20 dB (H-plane) pada sudut $0^{0}$. Nilai gain minimum antenna circular loop pada jarak 2 meter, 2.5 meter, 3 meter dan 5 meter sebesar $-20 \mathrm{~dB}$ (E-plane) dan $-20 \mathrm{~dB}$ (H-plane) seperti yang disajikan pada tabel 10. Ini berarti bahwa beamwidth antenna circular loop pada kondisi Loss sebesar $-20 \mathrm{~dB}$ dikurangi setengah daya $3 \mathrm{~dB}$, maka diperoleh $-23 \mathrm{~dB}$, sehingga half power beamwidth vertical (untuk jarak 1.5 meter) sebesar $20^{\circ}+30^{\circ}=50^{\circ}$, seperti yang terlihat pada gambar 8 berikut :

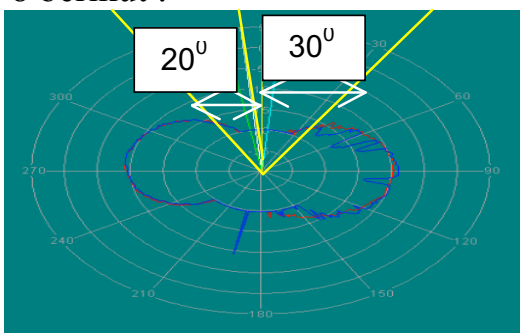

Gambar 8. Perhitungan Lebar Sudut Beamwidth

Hasil pengukuran gain rata-rata antenna circular loop pada kondisi loss dan 3 variasi posisi antenna circular loop yaitu E-plane, Hplane dan kombinasi (E-plane dan H-plane) akan disajikan pada tabel 5 .

Tabel 5. Nilai gain rata-rata antenna circular loop pada kondisi Loss

\begin{tabular}{|c|c|c|c|}
\hline \multirow[t]{2}{*}{$\begin{array}{c}\text { Jarak } \\
\text { antenna } \\
\text { (meter) }\end{array}$} & \multirow[t]{2}{*}{$\begin{array}{c}\text { E-Plane } \\
\text { (horizontal- } \\
\text { horisontal) }\end{array}$} & \multirow[t]{2}{*}{$\begin{array}{c}\text { H-Plane } \\
\text { (vertical- } \\
\text { vertikal) }\end{array}$} & $\begin{array}{c}\text { Kombinasi E-Plane } \\
\text { dan H-Plane } \\
\text { (horizontal - vertical) }\end{array}$ \\
\hline & & & E-Plane H-Plane \\
\hline
\end{tabular}

ISSN $2338-6649$

\begin{tabular}{ccccc}
\hline $\mathbf{1 . 5}$ & $-9.0 \mathrm{~dB}$ & $-14.3 \mathrm{~dB}$ & $-15.4 \mathrm{~dB}$ & $-15.3 \mathrm{~dB}$ \\
$\mathbf{2}$ & $-18.4 \mathrm{~dB}$ & $-19 \mathrm{~dB}$ & $-19.1 \mathrm{~dB}$ & $-19.1 \mathrm{~dB}$ \\
$\mathbf{2 . 5}$ & $-19.8 \mathrm{~dB}$ & $-18.2 \mathrm{~dB}$ & $-18.31 \mathrm{~dB}$ & $-19.7 \mathrm{~dB}$ \\
$\mathbf{3}$ & $-20.0 \mathrm{~dB}$ & $-20.0 \mathrm{~dB}$ & $-20.0 \mathrm{~dB}$ & $-20.0 \mathrm{~dB}$ \\
$\mathbf{5}$ & $-20.0 \mathrm{~dB}$ & $-20.0 \mathrm{~dB}$ & $-20.0 \mathrm{~dB}$ & $-20.0 \mathrm{~dB}$ \\
\hline $\begin{array}{c}\text { Gain } \\
\text { rata-rata }\end{array}$ & $\mathbf{- 1 7 . 4 4} \mathbf{d B}$ & $\mathbf{- 1 8 . 3} \mathbf{d B}$ & $\mathbf{- 1 8 . 5 6} \mathbf{d B}$ & $\mathbf{- 1 8 . 8 2} \mathbf{d B}$ \\
& & & & \\
\hline
\end{tabular}

Nilai gain antenna circular loop yang disajikan pada tabel 5 memperlihatkan ada 4 data hasil pengukuran gain rata-rata yang menyimpang dari pernyataan teori. Pertama yaitu pada kondisi kombinasi E-plane H-plane, pada jarak 2 meter, nilai gain rata-rata pada $-19.1 \mathrm{~dB}$ dan pada jarak 2.5 meter, nilai gain rata-rata $18.31 \mathrm{~dB}$. Kedua yaitu pada kondisi H-plane, pada jarak 2 meter, nilai gain rata-rata pada -19 dB dan pada jarak 2.5 meter, nilai gain rata-rata $-18.2 \mathrm{~dB}$. Berarti prosentase keakuratan hasil pengukuran gain rata-rata antenna circular loop kondisi LOSS adalah sebagai berikut :

$\%$ keakuratan $=\frac{(20-4)}{20} \times 100 \%=80 \%$

\section{Pengukuran Beamwidth, Gain dan Pola radiasi Antenna Circular Loop pada kondisi No-Loss}

Nilai gain minimum pada jarak 1.5 meter, sebesar -20 dB (E-plane) dan -20 dB (H-plane) pada sudut $0^{0}$. Nilai gain minimum antenna circular loop pada jarak 2 meter, 2.5 meter, 3 meter dan 5 meter sebesar $-20 \mathrm{~dB}$ (E-plane) dan -20 dB (H-plane) seperti yang disajikan pada tabel 16. Ini berarti bahwa beamwidth antenna circular loop pada kondisi No-Loss sebesar $-20 \mathrm{~dB}$ dikurangi setengah daya $3 \mathrm{~dB}$, maka diperoleh $-23 \mathrm{~dB}$, sehingga half power beamwidth vertical (untuk jarak 1.5 meter) sebesar $20^{\circ}+30^{\circ}=50^{\circ}$, seperti yang terlihat pada gambar 9 berikut :

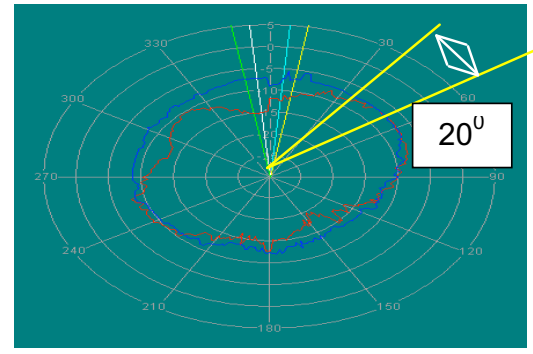

Gambar 9. Perhitungan Lebar Sudut Beamwidth

Hasil pengukuran gain rata-rata antenna circular loop pada kondisi No-Loss dan 3 variasi posisi antenna circular loop yaitu E-plane, H-plane dan kombinasi (E-plane dan H-plane) akan disajikan pada tabel 6 . 
Tabel 6. Nilai gain rata-rata antenna circular loop pada kondisi No-Loss

\begin{tabular}{|c|c|c|c|c|}
\hline \multirow[t]{2}{*}{$\begin{array}{c}\text { Jarak } \\
\text { antenna } \\
\text { (meter) }\end{array}$} & \multirow[t]{2}{*}{$\begin{array}{c}\text { E-Plane } \\
\text { (horizontal- } \\
\text { horisontal) }\end{array}$} & \multirow[t]{2}{*}{$\begin{array}{l}\text { H-Plane } \\
\text { (vertical- } \\
\text { vertikal) }\end{array}$} & \multicolumn{2}{|c|}{$\begin{array}{c}\text { Kombinasi E-Plane } \\
\text { dan H-Plane } \\
\text { (horizontal - vertical) }\end{array}$} \\
\hline & & & E-Plane & H-Plane \\
\hline 1.5 & $-14.3 \mathrm{~dB}$ & $-15.5 \mathrm{~dB}$ & $-15.4 \mathrm{~dB}$ & $-18.6 \mathrm{~dB}$ \\
\hline 2 & $-19.5 \mathrm{~dB}$ & $-15.1 \mathrm{~dB}$ & $-19.2 \mathrm{~dB}$ & $-19.7 \mathrm{~dB}$ \\
\hline 2.5 & $-19.4 \mathrm{~dB}$ & $-17.3 \mathrm{~dB}$ & $-19.1 \mathrm{~dB}$ & $-19.9 \mathrm{~dB}$ \\
\hline 3 & $-20.0 \mathrm{~dB}$ & $-20.0 \mathrm{~dB}$ & $-20.0 \mathrm{~dB}$ & $-20.0 \mathrm{~dB}$ \\
\hline 5 & $-20.0 \mathrm{~dB}$ & $-20.0 \mathrm{~dB}$ & $-20.0 \mathrm{~dB}$ & $-20.0 \mathrm{~dB}$ \\
\hline $\begin{array}{c}\text { Gain } \\
\text { rata-rata }\end{array}$ & $-18.64 \mathrm{~dB}$ & $-17.58 \mathrm{~dB}$ & $-18.74 \mathrm{~dB}$ & $-19.64 \mathrm{~dB}$ \\
\hline
\end{tabular}

Nilai gain antenna circular loop yang disajikan pada tabel 6 memperlihatkan ada 4 data hasil pengukuran gain rata-rata yang menyimpang dari pernyataan teori. Pertama yaitu pada kondisi kombinasi E-plane H-plane, pada jarak 2 meter, nilai gain rata-rata pada -19.2 dB dan pada jarak 2.5 meter, nilai gain rata-rata $-19.1 \mathrm{~dB}$. Kedua yaitu pada kondisi E-plane, pada jarak 2 meter, nilai gain rata-rata pada $-19.5 \mathrm{~dB}$ dan pada jarak 2.5 meter, nilai gain rata-rata $-19.4 \mathrm{~dB}$. Berarti prosentase keakuratan hasil pengukuran gain rata-rata antenna circular loop kondisi NO-LOSS adalah sebagai berikut :

$\%$ keakuratan $=\frac{(20-4)}{20} \times 100 \%=80 \%$

\section{Pengukuran Beamwidth, Gain dan Pola radiasi Antenna Yagi pada kondisi Loss}

Nilai gain minimum pada jarak 1.5 meter, sebesar -14 dB (E-plane) dan -20 dB (H-plane) pada sudut $210^{\circ}$. Nilai gain minimum antenna yagi pada jarak 2 meter, 2.5 meter, 3 meter dan 5 meter sebesar $-20 \mathrm{~dB}$ (E-plane) dan $-20 \mathrm{~dB}$ (H-plane) seperti yang disajikan pada tabel 10 . Ini berarti bahwa beamwidth antenna yagi pada kondisi Loss sebesar $-20 \mathrm{~dB}$ dikurangi setengah daya $3 \mathrm{~dB}$, maka diperoleh $-23 \mathrm{~dB}$, sehingga half power beamwidth vertical (untuk jarak 1.5 meter) sebesar $70^{\circ}$, seperti yang terlihat pada gambar 10 berikut :

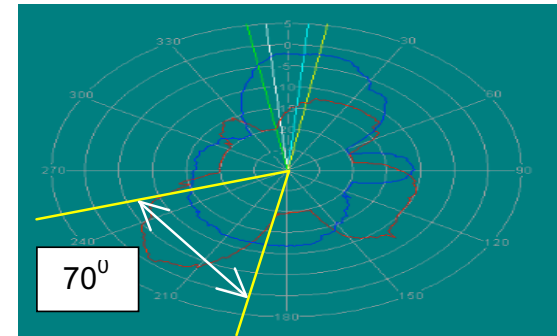

Gambar 10. Perhitungan Lebar Sudut Beamwidth

Hasil pengukuran gain rata-rata antenna yagi pada kondisi Loss dan 3 variasi posisi antenna yagi yaitu E-plane, H-plane dan kombinasi
(E-plane dan H-plane) akan disajikan pada tabel 7.

Tabel 7. Nilai gain rata-rata antenna yagi pada kondisi Loss

\begin{tabular}{|c|c|c|c|c|}
\hline \multirow[t]{2}{*}{$\begin{array}{l}\text { Jarak } \\
\text { antenna } \\
\text { (meter) }\end{array}$} & \multirow[t]{2}{*}{$\begin{array}{c}\text { E-Plane } \\
\text { (horizontal- } \\
\text { horisontal) }\end{array}$} & \multirow[t]{2}{*}{$\begin{array}{l}\text { H-Plane } \\
\text { (vertical- } \\
\text { vertikal) }\end{array}$} & \multicolumn{2}{|c|}{$\begin{array}{c}\text { Kombinasi E-Plane dan } \\
\text { H-Plane } \\
\text { (horizontal - vertical) }\end{array}$} \\
\hline & & & E-Plane & H-Plane \\
\hline 1.5 & $-14.5 \mathrm{~dB}$ & $-13.7 \mathrm{~dB}$ & $-14 \mathrm{~dB}$ & $-14.3 \mathrm{~dB}$ \\
\hline 2 & $-14.54 \mathrm{~dB}$ & $-16.5 \mathrm{~dB}$ & $-18.2 \mathrm{~dB}$ & $-17.8 \mathrm{~dB}$ \\
\hline 2.5 & $-17.4 \mathrm{~dB}$ & $-19.6 \mathrm{~dB}$ & $-18.98 \mathrm{~dB}$ & $-19 \mathrm{~dB}$ \\
\hline 3 & $-20.0 \mathrm{~dB}$ & $-20.0 \mathrm{~dB}$ & $-20.0 \mathrm{~dB}$ & $-20.0 \mathrm{~dB}$ \\
\hline 5 & $-20.0 \mathrm{~dB}$ & $-20.0 \mathrm{~dB}$ & $-20.0 \mathrm{~dB}$ & $-20.0 \mathrm{~dB}$ \\
\hline $\begin{array}{l}\text { Gain } \\
\text { rata- } \\
\text { rata }\end{array}$ & $-17.19 \mathrm{~dB}$ & $-17.96 \mathrm{~dB}$ & $-18.24 \mathrm{~dB}$ & $-18.22 \mathrm{~dB}$ \\
\hline
\end{tabular}

Nilai gain antenna yagi kondisi Loss yang disajikan pada tabel 7 menujukkan semakin bertambah jarak, maka nilai gain rata-rata akan semakin menurun, sehingga prosentase keakuratan hasil pengukuran gain antenna yagi sangat sempurna sebesar :

$\%$ keakuratan $=\frac{(20-0)}{20} \times 100 \%=100 \%$

\section{Pengukuran Beamwidth, Gain dan Pola radiasi Antenna Yagi pada kondisi No- Loss}

Nilai gain minimum pada jarak 1.5 meter, sebesar -20 dB (E-plane) dan -13 dB (H-plane) pada sudut $300^{\circ}$. Nilai gain minimum antenna yagi pada jarak 2 meter, 2.5 meter, 3 meter dan 5 meter sebesar $-20 \mathrm{~dB}$ (E-plane) dan $-20 \mathrm{~dB}$ (H-plane) seperti yang disajikan pada tabel 22. Ini berarti bahwa beamwidth antenna yagi pada kondisi No-Loss sebesar $-20 \mathrm{~dB}$ dikurangi setengah daya $3 \mathrm{~dB}$, maka diperoleh $-23 \mathrm{~dB}$, sehingga half power beamwidth vertical (untuk jarak 1.5 meter) sebesar $70^{\circ}$, seperti yang terlihat pada gambar 11 berikut :

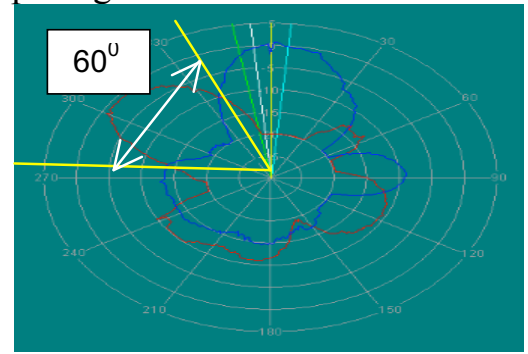

Gambar 11. Perhitungan Lebar Sudut Beamwidth

Hasil pengukuran gain rata-rata antenna yagi pada kondisi No-Loss dan 3 variasi posisi antenna yagi yaitu E-plane, H-plane dan kombinasi (E-plane dan H-plane) akan disajikan pada tabel 8 . 
Tabel 8. Nilai gain rata-rata antenna yagi pada kondisi No- Loss

\begin{tabular}{ccccc}
\hline $\begin{array}{c}\text { Jarak } \\
\text { antenna } \\
\text { (meter) }\end{array}$ & $\begin{array}{c}\text { E-Plane } \\
\text { (horizontal- } \\
\text { horisontal) }\end{array}$ & $\begin{array}{c}\text { H-Plane } \\
\text { (vertical- } \\
\text { vertikal) }\end{array}$ & $\begin{array}{c}\text { Kombinasi E-Plane dan } \\
\text { H-Plane } \\
\text { (horizontal - vertical) }\end{array}$ \\
\cline { 4 - 5 } & $-13 \mathrm{~dB}$ & $-14.1 \mathrm{~dB}$ & $-14.7 \mathrm{~dB}$ & $-14.3 \mathrm{~dB}$ \\
\hline $\mathbf{2}$ & $-17.1 \mathrm{~dB}$ & $-17.5 \mathrm{~dB}$ & $-18.3 \mathrm{~dB}$ & $-18.4 \mathrm{~dB}$ \\
\hline $\mathbf{2 . 5}$ & $-18.5 \mathrm{~dB}$ & $-19.9 \mathrm{~dB}$ & $-19.2 \mathrm{~dB}$ & $-18.4 \mathrm{~dB}$ \\
\hline $\mathbf{3}$ & $-20.0 \mathrm{~dB}$ & $-20.0 \mathrm{~dB}$ & $-20.0 \mathrm{~dB}$ & $-20.0 \mathrm{~dB}$ \\
\hline $\mathbf{5}$ & $-20.0 \mathrm{~dB}$ & $-20.0 \mathrm{~dB}$ & $-20.0 \mathrm{~dB}$ & $-20.0 \mathrm{~dB}$ \\
\hline $\begin{array}{c}\text { Gain } \\
\text { rata-rata }\end{array}$ & $\mathbf{- 1 7 . 7 2 ~ d B}$ & $\mathbf{- 1 8 . 3 ~ d B}$ & $\mathbf{- 1 8 . 4 4 ~ d B}$ & $\mathbf{- 1 8 . 2 2 ~ d B}$ \\
& & & &
\end{tabular}

Nilai gain antenna yagi kondisi No-Loss yang disajikan pada tabel 8 menujukkan semakin bertambah jarak, maka nilai gain ratarata akan semakin menurun, sehingga prosentase keakuratan hasil pengukuran gain antenna yagi sangat sempurna sebesar :

$\%$ keakuratan $=\frac{(20-0)}{20} \times 100 \%=100 \%$

Secara keseluruhan, hasil perhitungan gain rata-rata untuk 4 jenis antenna penerima (antenna dipole, antenna monopole, antenna circular loop dan antenna yagi) menunjukkan bahwa antenna yagi yang memiliki karakteristik yang paling bagus karena nilai gain dan pola radiasinya sangat ideal dan sempurna secara teoritis. Untuk lebih jelasnya, prosentase hasil pengukuran gain rata-rata 4 jenis antenna penerima pada kondisi LOSS dan NO-LOSS dengan 5 variasi jarak, disajikan pada tabel 9 berikut ini :

Tabel 9. Prosentase keakuratan hasil perhitungan nilai gain rata-rata untuk 4 jenis antenna penerima

\begin{tabular}{ccccc}
\hline Kondisi & $\begin{array}{c}\text { Antena } \\
\text { Dipole }\end{array}$ & $\begin{array}{c}\text { Antena } \\
\text { Monopole }\end{array}$ & $\begin{array}{c}\text { Antena } \\
\text { Circular } \\
\text { Loop }\end{array}$ & $\begin{array}{c}\text { Antena } \\
\text { Yagi }\end{array}$ \\
\hline LOSS & $100 \%$ & $90 \%$ & $80 \%$ & $100 \%$ \\
\hline $\begin{array}{c}\text { NO- } \\
\text { LOSS }\end{array}$ & $90 \%$ & $80 \%$ & $80 \%$ & $100 \%$ \\
\hline
\end{tabular}

Berdasarkan tabel 9, prosentase keakuratan antenna yagi sangat sempurna yaitu $100 \%$, baik saat kondisi LOSS maupun NO-LOSS. Maka dapat disimpulkan bahwa antenna yagi sangat cocok digunakan secara umum, baik sebagai antenna pemancar maupun sebagai antenna penerima, karena nilai gain dan pola radiasinya sangat ideal baik dan telah dibuktikan dengan 5 variasi jarak, 3 posisi antenna dengan 12 derajat kemiringan dan 2 kondisi antenna (LOSS dan NO-LOSS).

\section{KESIMPULAN}

Berdasarkan hasil analisa, maka dapat ditarik kesimpulan bahwa parameter beamwidth, gain dan pola radiasi antenna mempengaruhi performansi antenna penerima. Perubahan nilai beamwidth pada antenna penerima yagi saat kondisi Loss dan No-Loss hampir dikatakan tidak terlalu mengalami perbedaan, hanya selisih $10^{\circ}$, dibandingkan perubahan beamwidth pada antenna dipole, antenna monopole dan antenna circular loop. Ini berarti bahwa performansi antena yagi sangat bagus dibandingkan antena penerima lainnya. Gain antenna dipengaruhi oleh jarak antenna pemancar dan penerima. Semakin jauh jarak antara antenna pemancar dan antenna penerima, maka nilai gain antena akan mengalami penurunan. Hasil pengujian performansi antenna penerima menunjukkan bahwa diantara 4 jenis antenna (dipole, monopole, circular loop dan yagi), terbukti bahwa antenna yagi memiliki tingkat akurasi pengujian yang sangat sempurna sebesar $100 \%$. Antena yagi terbukti memiliki nilai beamwidth, gain dan pola radiasi yang sangat ideal, sehingga sangat cocok diimplementasikan sebagai antenna pemancar dan antenna penerima.

\section{SARAN}

Untuk penelitian selanjutnya, dapat ditambahkan parameter uji lainnya seperti directivity antena dan penambahan nilai frekuensi kerja antena.

\section{UCAPAN TERIMA KASIH}

Puji syukur kepada Allah, SWT, karena penelitian ini dapat diselesaikan dengan sebaikbaiknya dengan waktu semaksimal mungkin. Oleh karena itu, kami menghaturkan banyak terima kasih kepada pihak-pihak yang turut membantu dan mendukung terlaksananya pengambilan data pada penelitian ini. Terutama kepada Ketua Jurusan Teknik Elektronika yang telah memperkenankan kami untuk menggunakan Laboratorium 4G sebagai lokasi pengambilan data. Ucapan terima kasih juga kami persembahkan kepada Laboran TE dan beberapa mahasiswa TE, sehingga penelitian ini dapat diselesaikan sesuai target waktu yang diberikan.

\section{DAFTAR PUSTAKA}

[1] Budi Pratama, "Perancangan dan implementasi antena yagi $2.4 \mathrm{GHz}$," Jurnal Elkomika, 2013.

[2] Deden Nur Rokhman, "Implementasi antena yagi 5 elemen sebagai penerima siaran televisi di Bandung kota," Juli 2016.

[3] John D.Krous,.: McGraw-Hill Book Company, 
1988.

[4] Nasrul, "Pembuatan Antena Triband untuk kendaraan bergerak," Jurnal $R \& B$, vol. VolumeIII, 2003.

[5] A.Zulkifli Lubis, "Pengaruh posisi antena terhadap sinyal gelombang antena yagi aluminium," Jurnal Dinamis, vol. Volume II Nomor 14, 2014.

[6] Hamzah. (2016) Hamzah Blog's. [Online]. HYPERLINK

"http://widuribarru.blogspot.co.id/p/jenisantena.html"

http://widuribarru.blogspot.co.id/p/jenisantena.html

[7] YD2TFB. (2011) Antena Dipole dan Monopole. [Online]. HYPERLINK "http://www.google.co.id/search?q=polaradiasi +dipole+antena\&source" http://www.google.co.id/search?q=polaradiasi+ dipole+antena\&source

[8] Abi. (2015) Memahami Jenis Antena Monopole. [Online]. HYPERLINK "http://www.google.co.id/search?q=polaradiasi +monopole+antenna\&source" http://www.google.co.id/search?q=polaradiasi+ monopole+antenna\&source

[9] Hanardi Satrio. (2014) Perancangan Antena Dual Circular Loop sebagai penerima siaran televisi digital pada rentang frekuensi UHF. [Online]. HYPERLINK

"http://www.google.co.id/search?q=pola+radias $\mathrm{i}+\mathrm{ideal}+$ antena+circular+loop\&tbm" http://www.google.co.id/search?q=pola+radiasi +ideal+antena+circular+loop\&tbm

[10] Dahlan Abdullah. (2013) Sistem Antena. [Online]. HYPERLINK "http://dahlan.web.id" http://dahlan.web.id 